\title{
THE MOTIVATION OF COLLABORATORS IN FAMILY MICRO COMPANIES: CYBERCAFÉ
}

\author{
JOSÉ G. VARGAS-HERNÁNDEZ \\ University of Guadalajara (UdeG), Los Belenes, Zapopan - (Jalisco) - Mexico. \\ JOSÉ ANGEL ARREOLA-ENRÍQQUEZ \\ University of Guadalajara (UdeG), Los Belenes, Zapopan - (Jalisco) - Mexico.
}

To cite this paper: Vargas-Hernández, J. G. \& Arreola-Enríquez, J. A. (2017). The motivation of collaborators in family micro companies: cybercafé. Revista de Administração Mackenzie, 18(6), 149-176. doi 10.1590/1678-69712017/administracao.v18n6p149-176 


\section{ABSTRACT}

Purpose: The purpose of this study is to analyze the motivation of collaborators based on the Maslow pyramid, in order to have an approach to the subject of motivation in family micro-businesses, such as cybercafé, where business is income from computer systems and the internet.

Originality/value: This paper is original to find solutions to the existent gap in motivating collaborators of micro family business dedicated to the service of renting computers for the Internet. The main implication is to generate proposals for the improvement of labor motivation in the aforementioned family micro-enterprises.

Design/methodology/approach: A questionnaire elaborated on the scale of Likert is applied to diagnose motivation and job satisfaction starting from the Maslow pyramid. With a sample of 7 employees, who work in the company mentioned above, the questionnaire was applied to Google forms.

Summary of key results: The results presented by the study of job motivation in cybercafé are not favorable to the company, due to the representativeness showed by the "indifferent" option chosen by the employees in the scenarios presented in the questionnaire. This can create uncertainty due to the impartiality or to some extent insecurity in the employee when choosing the option "indifferent".

Findings: Labor motivation in the family micro-business partners may be a little complex to address under the Maslow theory, and in general, that of any models, which have been developed, because of to the environment, in which these family companies are set up and operate.

\section{KEYWORDS}

Motivation. Maslow pyramid. Cybercafés. Micro enterprises. Internet. 


\section{INTRODUCTION}

In some of the companies in Mexico, creation starts as a micro enterprise, based on the stratification mentioned in the INEGI report of 2009, with a number of workers less than 10 people. Therefore, this size of companies is reduced, coupled with the fact that some of them are family businesses. Therefore, the management of this type of business is facing increasingly complex challenges, as in the case of some elements of the labor climate, such as motivation.

For this type of business, the theoretical concepts about management may be scarce to be applied. That is, they operate the vast majority based on empirical knowledge generated by experience, which, based on trial and error, make them vulnerable in several problems of the company as they are, staff turnover due to lack of motivation and as a result low job satisfaction. This is a trigger for the managers' decision-making and seeks strategies that counteract the problems of job motivation.

It should be noted that this problem is more clearly defined when the employers detect a decrease in their usefulness, low productivity in employees and when the clients express their dissatisfaction with poor service, among others.

There are theories focused on the study of motivation, which determines the factors or elements that explain the people's behavior to the elements that motivate them to perform some activities, both in the particular situation and in the workplace. This study is based on the Maslow pyramid, to have an approach to the subject of motivation in micro-businesses such as cybercafé, where business is the income from computer systems and the internet. In the case of Maslow's security needs, this section of the survey is not applied because there are no elements to evaluate it, so the results would be biased.

\section{BACKGROUND OF THE PROBLEM AND CONTEXTUAL FRAMEWORK}

The evolution of the information and communication technology (ICT) based on the Internet has called for business schemes that provide computer rental services with Internet for people to perform specific activities, such as social relations and exchange of information at the global level, where cities 
have been influenced by economic factors operating at great distances (Giddens, 2000, 2007).

For users to have an internet connection in a space where they can lease computer equipment to access the world of the internet, it is attractive because they do not need to acquire a computer outside of their budget, under the context, it can be said that Internet cafés are affordable for users (Finquelievich, 2002). In addition to Internet accessibility for users, the proliferation of cybercafés is linked to the lack of Internet access or computers in homes (Fisher, 1984).

Established businesses as cybercafés were places where young people migrated to a new digital stage, where the combination of elements in their environment, such as economic, cultural, social and spatial, places them in a virtual and face-to-face environment (Moscovici and Miles Hewstone, 1984).

According to Becerra (2011), among the first antecedents of cybercafés in Mexico is a publication that is titled "Now coffee is taken in the Internet?" from Colegio de Sonora published by Castro Luque and collaborators. In 2006, the Autonomous University of Mexico (UNAM) carried out another study called "Public Internet access: Cybercafés in Mexico", aimed at clients of these businesses with characteristics of cultural-educational centers for new societies. Also supported by another study developed by Rueda in 2004, where he emphasizes technology as a tool for problem-solving, focused on cybercafé.

In Guadalajara, the data on the creation of the first cybercafé was from 1997, located in the Olympic zone, where the Internet connection was precarious and without public support. To contextualize the expansion of technology, it is convenient to explore the territorial and social effects corresponding to the commercial spaces of cities; in this case, Internet cafés show the influence of globalization and the interaction of individuals through technology in question of the communication (García, 2008).

\section{DELIMITATION OF THE PROBLEM}

Motivation is a very broad issue, even if it is intended to deal with business aspects. There are several theories and models that may not be applied to all companies or industries for several reasons; cultural, company size, the profile of employees and managers, customers, suppliers, among others. In this case, micro-enterprises are born as a need to obtain a resource perhaps faster, and this places them in a complicated position in administrative and personnel management. 
Usually, micro enterprises are born without a structure, which is built as time passes and in some cases, decisions are based on empirical knowledge. In addition to the above, the management of the personnel and the process of their motivation are extremely complex. However, micro-businesses exist and struggle day by day to stay and grow with the available means. Therefore, cybercafés are within the concepts described above. For this purpose, a cybercafé with 7 collaborators is characterized as a case study in this work, trying to investigate the collaborators' motivation, taking the Maslow pyramid as a reference.

\section{JUSTIFICATION}

One of the problems faced by service micro-enterprises is the lack of a study that helps them to determine the level of job motivation that their employees have in their company, and with that, to know the problems they face and create strategies that help them improve the working climate and, as a consequence, create a positive impact on profitability.

Cybercafés are companies that are mostly not large. However, it has relevance in the matter of technology in communications based on the internet, and on the other hand, accessibility and availability for all people regardless of the individuals' knowledge or conditions about the management of technologies (Toudert \& Buzai, 2004). In addition, it is the social impact with effects of improvement in the people's quality of life within an environment that contains a group of services, such as networks, software, among other devices (Ibáñez, 1998).

Nowadays, the challenges presented by the network society are derived from the evolution of technologies in media and communication, considered important elements in modern organizations, such as cybercafés (Castells, 2002).

In terms of employees of Internet cafés, Becerra (2011), in his book "The cyber in Guadalajara", argues that they are usually familiar, and their training is basically under basic knowledge about the performance of activities, unlike the owners who are usually people with knowledge about ICT (Information and Communication Technologies) and professionals, where their objective is to make an investment in a business that is related to their academic training. However, the business management has become complicated among them, the management of staff working in cybercafés, and this is learned from experience, where the employees' motivation is an important part of the business. 


\section{ASSUMPTION}

The motivation of the collaborators in the microenterprises dedicated to the lease of computer equipment and Internet is negatively affected by the lack of economic compensations according to the activities that are carried out.

\section{PURPOSE}

To evaluate the needs of the Maslow pyramid of the collaborators in the microenterprises of computer and internet rental services.

\section{THE FAMILY BUSINESS}

The theoretical assumption is that there are intrinsic limiting factors, which are those that have the greatest impact on the lifetime of family businesses. Some current conceptions of what is a family business are as follows: As Nelson (2014, p. 72) states, "for a Family Business to exist, there is need that not only the components announced remain in time, but also the family group responsible for managing what will later become the family heritage." Donnelley (1964, p. 149) "A company in which they have identified at least two generations of a family and that link has influenced the company's policies and the family's interests and objectives." Analyzing both definitions, it can be highlighted that there are two determinants; the family and the company.

That is, in these two types of organizations, social entities converge, the first one based on kinship and cordiality; and the second, where formal and efficient relationships predominate. This poses a complication in the company organizational fruit of its own nature. However, Gersick, Davis, Hampton \& Landsberg (1997) analyze this interaction and adhere to another element property. The same refers to the possession of shares of the company. So that supports a number of possibilities: a member of the family, working in the company but not owning shares. On the other hand, working in the company, have shared and not be a member of the family, among others. The following Figure 1 shows the variety of possible relationships. 


\section{(Figure 1)}

\section{THE MODEL OF THE THREE CIRCLES}

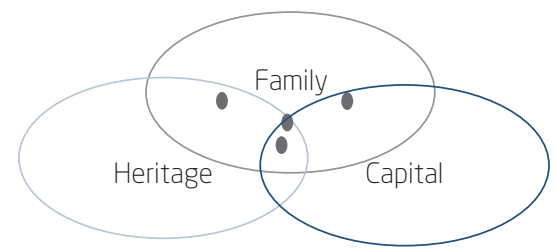

Source: Adapted from López-Cozar and Priede Bergamini (2009).

We add up motivation to these elements as shown in Figure 2 below.

\section{(Figure 2)}

\section{THE MODEL OF THE FOUR CIRCLES}

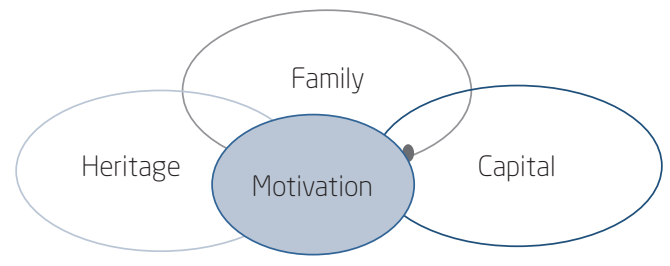

Source: Elaborated by the authors.

This new model emphasizes the importance of motivation. In addition to this, a quantitative parameter to classify these economic entities is based on the number of workers they have, which vary depending on the sector, as shown in the following chart:

\section{(Chart 1)}

STRATIFICATION OF THE COMPANY IN MEXICO

\begin{tabular}{|c|c|c|c|}
\hline \multirow{2}{*}{ Size } & \multicolumn{3}{|c|}{ Sector } \\
\hline & Industry & Trade & Services \\
\hline Micro & $0-30$ & $0-5$ & $0-20$ \\
\hline Small & $31-100$ & $6-20$ & $21-50$ \\
\hline Medium & $101-500$ & $21-100$ & $51-100$ \\
\hline Large & 501 hereinafter & 101 hereinafter & 101 hereinafter \\
\hline
\end{tabular}


As it can be seen, the latter classification is leaving the fact that the company may or may not be of familiar nature aside. This is because there is no limitation for that family businesses to grow or not, therefore, to work on more objective classifications, the one above has been established.

Before continuing, it should be noted that the fact that family businesses do not indicate that they have to be necessary of small or short longevity. Since there are cases of family-owned companies, which are considered among the largest or the oldest in the world. Such is the case of the Tequila Jose Cuervo, which was founded in 1758 and is the oldest family-owned business in Mexico today, and America Movil of Carlos Slim, which is in the ranking of the largest companies in the world according to Forbes 2015. However, subject to the problems posed by this work, it is assumed that most family businesses are micro and small sized, limiting the study to them.

These contradictory scenarios have caught the attention of some scholars. Therefore, the possible causes that lead to these companies to fail have been studied. First, it is necessary some factors be present in the context, in which it is developed and others are born in the nature of the company. For this work, both views are mentioned, with reference to the factors identified by Nelson (2014), López Contreras and Molina (2013) and García \& Dávila (2012). On the one hand, internal aspects are analyzed as lack of planning, inheritance, nepotism, handling, and organization. And in relation to the economic aspects, those linked to the administrative aspect, such as liquidity, solvency, profitability, and efficiency.

\subsection{Intrinsic problems of the family business}

\subsubsection{Lack of planning - behavioral theory of the firm}

A large number of family businesses are born by a circumstantial initiative. So, at first, to determine what to do and how to do it are questions that capture the attention of their creators, who give answers to these questions as they become essential. Forgetting one of the four administrative pillars of the company, which is planning, this can be operated from the enthusiasm and motivation product of wishful thinking that accompanies the birth of a business. However, the absence of a growth plan established as a path to follow, the long-term goals are ambiguous, which can be translated into disarray; it must be dissipated by the executives, as they tell the behavioral theory of the firm.

Another kind of problem caused by the lack of organization is the failure of cooperation by disintegration that can lead to the destruction of its own 
company. This can be solved by transmitting the idea of a common purpose to all members, reconciling everyone's interests and channeling work to the pursue mutual and not individual benefit. Otherwise, it will result in companies that fail to establish their projections of growth in real terms, in addition to establishing their action plans based on their capabilities, they will be those that fail to stay on the market, as Nelson and Winter (1928; 2002) pointed out in their theory of evolution.

\subsubsection{Succession - Agency theory}

One of the most delicate and controversial issues within the life of family businesses is the transition of authority from the founder to the successor, or from the successor or his successor. The difficulties surrounding this transition are varied. Based on the role to be played by this person, it falls into the first difficulty; not all companies have a well-established succession policy. This causes many discrepancies that exist when selecting a candidate since there are no parameters to justify the responsible act in turn. As Press (2011) mentioned, some of the issues discussed by founders at the time of the transition are related to the distrust of the new generation, fear of conflicts between heirs, fear of life without their main occupation and fear to depend on someone financially.

Factors that will inevitably provoke disagreements in the family are bringing all kinds of problems. That is because the recommendation is precise to establish mechanisms to continue to give the company the right candidate. For Nelson (2014), the purpose of succession is fundamental to get the company to grow. Therefore, it is necessary to identify a person who has the vision and the capabilities to achieve the possible development and growth. After analyzing whether the person has qualities like born leadership, reflected in the ability to inspire confidence, to end despair, fight fear, and define objectives and thus the future of everyone involved. Later, he continues his preparation.

One of the strategies used to ensure that the choice is adequate is the head of the company to find one or two people who start preparing as to the activities to be developed for the correct address of the firm. Through a course of training, development and familiarization activities and decisions that are vital to the family business. It is important to note that this person or these people, to whom confidence and hope of good management are given, must meet a number of requirements, among which the fact to accept this responsibility willingly stands out. 
Contrary to popular beli \ef, it is not necessary for the successor to be the firstborn son. There are cases of companies considering that the successor attached to this tradition - is not adequate, seeking a third individual. This is where the theory of the agent becomes relevant. This theory states that at the inability of the family to project a proper planning or management, to opt for hiring an external person with the required expertise to implement relevant actions that generate an increase in profits for the firm. This person is called agent.

On one hand, this option seems to promise peace of mind to business owners and owners of capital, in addition to being a guarantee for the entry of higher profits. But this greed or unquenchable longing for more can generate major moral distrust, his agent not to be watching all his actions, and therefore give space to opportunism. As a method to reduce theese mistrust monitoring mechanisms can be established, which in turn represent an expense for the company and can be interpreted by the agent as an attack on his integrity, impacting negatively on his performance. In addition to this, another issue that may raise is the difficulty in determining the sections control or define the authority, which is exceeded only when one party is superimposed on the other.

It also happens that because of this distrust, the information flow from principal to the agent, or vice versa, is not entirely accurate or timely, generating information asymmetries and therefore uncoordinated or not approved actions. However, the company must analyze the professional in charge who accepts responsibility and deposit trust in him; he has a prestige and remuneration to lose in case of falling into these errors.

\subsubsection{Nepotism}

One of the common problems in the family business is nepotism. Nepotism is considered by the Dictionary of the Royal Spanish Academy (Gonzalez, 1822, pp. 1052.) as "undue preferences that some give to their relatives for concessions or public jobs." Considering the nature of these firms, nepotism can be considered a common practice. However, it can fall into the extreme nepotism.

A common mistake is to admit people to the families with no preparation related to the company, sometimes giving those positions that are relevant in terms of decision-making. These decisions reflect a wobbly and very susceptible blackmail or family sentimentality authority. One consequence of this practice is the waste of scarce resources and inefficient performance. 
A measure that can solve these practices is to require the family member, who wants to be part of the firm, to acquire knowledge and also experience in companies in the industry, and with the acquired sufficient knowledge, to perform his duties properly, then integrate him into the team.

As far as possible, nepotism can be practiced responsibly, ensuring the suitability of the family to fill positions and perform activities efficiently, impacting the lifetime of the company.

\subsubsection{Organization - behavioral theory of the firm}

In economy, to have a good organization within the company to combine individual efforts optimally to achieve group goals is considered. The easiest way to represent this is through a gear, where each piece has a field of action and within it, well-defined activities, but also to know the scope that has its work within the organization, which in turn generates sense of commitment and belonging to the person. Nacional Financiera recommended periodic analysis in the company to assess whether all employees are well aware of what their roles, responsibilities are, who their subordinates and immediate bosses are, as well as the activities that should not be performed. All this in order to detect any information gap and to cover it as soon as possible, because if these activities are not well defined, the business disorganization results.

In family businesses, it is common that positions are created without specifying the entire field of action, this in turn derived from lack of strategic planning. If a non-appropriate for the position profile is added to this, it is natural that the person feels unable to make decisions, and then it is inevitable to have problems, and centralization of decisions (López Contreras Molina, 2013) is inevitable. Failure to assess the implications and consequences of each action generates advice or approval by other people, who are usually the company's managers. Thus, the very nature of the organization is contradicted, i.e., a delegation of authority. One effect of this problem is the loss of opportunities for a delay in decision-making, and the extension of failures for not giving a timely solution.

Similarly, disorganization can be interpreted as lack of control at all levels of the organization, which can create the conditions for the emergence of abuse of trust, or the labor parasitism, that if left untreated, can lead the firm to bankruptcy.

A behavioral theory of the firm mentions this problem, noting the three basic elements that must be considered when designing an efficient organization, which are: the control unit, specialization functions, and 
decentralization. Having these distinct elements, objectivity is achieved in activities, reducing time and resources by information asymmetry.

\subsubsection{Lack of motivation}

It seems that motivation is already an inclusive and embedded factor in most oriented family business under the assumption that the main reason of existence is the family ownership. The following sections intend to explain why it is not assumed like that.

\section{THEORETICAL FRAMEWORK (THEORIES AND STUDIES IN MEXICO)}

Companies have been changing over time, as well as an evident evolution in their processes as the factor of human capital, which is related to the use of technologies to produce efficiency. Therefore, the administration of human capital as Chiavenato (2002) describes it, is a fundamental part of any organization, where tools, procedures, and people converge, where the evolution of organizations is expressed as the worker is replaceable machine because of the evolutionary capacity based on the possibility of increasing their abilities (Ackoff, 1997).

Munch (2005, p. 4) defines human capital as the value of the skills, abilities, experiences, and knowledge of the people who make an organization up. The concept was scribed in Edvinsson and Mollone (1999, p. 66) as the individuals, the knowledge, skills and experiences of the employees and managers of the organization. For Malgioglio et al. (2001, p. 352), the set of intangible resources owned by members belonging to an organization. Therefore, people's skills, and abilities can be leveraged with tools that boost performance and thus, generate factors that encourage motivation of individuals in organizations.

Working capital management requires an investment of monetary and time resources that enable employees to train for the acquisition of knowledge and skills development for the efficient performance of their current activities (Wayne, Noe, and Premeaux 1997, p. 230).

The motivation of people is a determining factor for the execution of activities within organizations. Among the tools that have been used to analyze motivation is the Maslow pyramid (Quintero, 2011, p. 1), in which a hierarchy of five needs is mentioned, that are: physiological, safety, association or acceptance, estimation and self-realization (Robbins, 1998, p. 169). 
With respect to the physiological needs, according to Maslow, they are the basic ones for the people and they refer to the human life. They are related to the preservation of the life, as they are: water, food, warmth, shelter, and dream. That is to say, without any of the aforementioned, there would be no human being or, in the absence of any of the ones mentioned in the course of life, people would go into decay or disappearance (Koontz, \& Weihrich, 2007, p 501).

Safety is another of the needs mentioned in Maslow's pyramid, which is related to emotions, consisting of assumptions where fears are expressed about loss of employment or health problems, an absence of food, clothing, or have the certainty of having a house where to live. On the other hand, the need for association or acceptance for Maslow (1943) is related to the physiological and security needs that would be passed to the level of acceptance, and the affection or the feeling of belonging to some group of people where friendship manifests itself.

Likewise, the needs of estimation in people are manifested in the society recognizing their achievements, coupled with a sense of freedom and be respected within it. And finally, the needs of self-realization, where it focuses more on the individual based on the potential to enhance something that people like (Maslow, 1943, p. 375).

The above-mentioned needs were not all Maslow determined regarding motivation. There are others that are more specific to groups of people, such as aesthetic needs, where he mentions the exterior beauty, cognitive needs that lie in the desire to know and explore intellect and the needs of selftranscendence. This goes beyond the self, where it focuses more on serving others, ideal or cause (Quintero, 2011).

Motivation is something that insists on creation of things and gives impulse to the movements as an engine to influence the people's activities (Carrillo et al., p. 21), and motivation provides direction and preservation of the individual's behavior due in part to the development of new projects (Naranjo, 2009, p 154). On the other hand, Santrock (2002) defines motivation as a set of elements that encourage people to perform activities under a structured scheme; such behavior contains a very high range of requirements to reach the goals.

\subsection{Needs of Henry Murray}

It is difficult to reach a consensus on the quantification of the human needs, even when they have been hierarchized or very generalized. For example, 
Henry Murray determined 20 human needs among which are psychogenetic and vicerogenetic that includes food, water and, oxygen. Other Murray's needs include depression, aggression, opposition, gambling, rejection, sex sensitivity, among others (Bourne, 1976, pp. 171-172).

\subsection{Theory of ERG Aldefer}

For Alderfer, in his theory, there are some similarities with the Maslow needs. However, Alderfer separates them and forms three blocks only unlike Maslow, which are: needs of existence that contains the physiological and security of the Maslow pyramid. The relationship needs described as those of association and growth needs that include the needs of self-realization and estimation focused on personal development, competitiveness and competition (Naranjo, 2009, p. 158).

The motivation in the administrative sciences falls into two essential elements, which are unsatisfactory elements, that is to say that they go against everything that generates a positive motivation, whereas the factors that are in favor of the motivation, are generators of growth and as a consequence, they produce high satisfaction, such as achievement, and recognition (Koontz \& Weihrich, 2007, p. 503).

\subsection{Other theories}

The theory of expectation was developed by Victor Vroom, where the motivation of people to perform some activity based on a certain value that is assigned at the end of their work is presented, it goes hand in hand with the trust deposited contributing to pay their efforts off (García, 2008). Therefore, the theory of equity with respect to motivation refers to individual contributions that together with other contributions generate the same benefit. The difference of benefit goes according to the activity, nevertheless, it seeks that everyone receives a reward for the work to play (Robbins, 1998, p. 183).

Among McClellend's representative needs in his theory, he refers to power as a need, which consists in influencing other people for a particular purpose. The need for achievement is related to the fact of standing out in a group of people above the standards until then. Finally, the need for affiliation, which is to belong to or relate to a group of people through friendship (McClelland \& Burnham 1976, p. 103). 


\section{METHODS}

In the micro-company dedicated to income from computer systems and internet is known commercially as Internet cafés, there is a questionnaire elaborated on the Likert scale to diagnose motivation and job satisfaction starting from the Maslow pyramid, where the following dimensions arise: 1. Physiological, 2. Security, 3. Social, 4. Estimate, and 5. Self-realization.

With a sample of 7 employees, who work in the company mentioned above, the questionnaire was applied to Google forms.

\section{ANALYSIS}

In order to analyze the results of the studies based on the survey carried out by the personnel working in the cybercafé, the following results were found, evidencing the importance of the collaborators' motivation to carry out their activities in an appropriate way.

In the Graphs presented below, their contents are described; corresponding to the $\mathrm{Y}$ axis (vertical), a number from 0 to 7 according to the number of collaborators. In this case, the coincidence between the number of workers and the response options, no more than 5. On the $\mathrm{X}$ axis (horizontal), there are the ranges to measure the degree of coincidence with the question, which is: 1 . Totally disagree, 2. Disagree, 3. Indifferent, 4. Agree and lastly, 5. Totally agree. Therefore, the intersection between the two axes results in the number of collaborators, who share the same opinion with respect to each question.

Physiological needs. Corresponding to this section four questions are asked, in which the following results are presented in the Graph 1.

In question number one, it is evaluated how the collaborators qualify the tools that they use to be able to carry out their tasks according to the requirements of their activities, which can be as an article of stationery, time controls, among others. The results show that three of the seven collaborators surveyed agree with the question, three other people are indifferent to the tools they use for their work, and finally, only one collaborator totally agrees with the tools that he uses according to the content of the question. Only one person answered in fully agreeing on the tools provided by the micro business. Emphasis should be placed on the people who answered that they are indifferent, they may not have defined the use of the tools or do not know their potential. 


\section{(Graph 1)}

ARE THE MEANS USED IN THE PERFORMANCE OF THEIR WORK CONDUCIVE TO CARRY OUT THEIR TASKS?

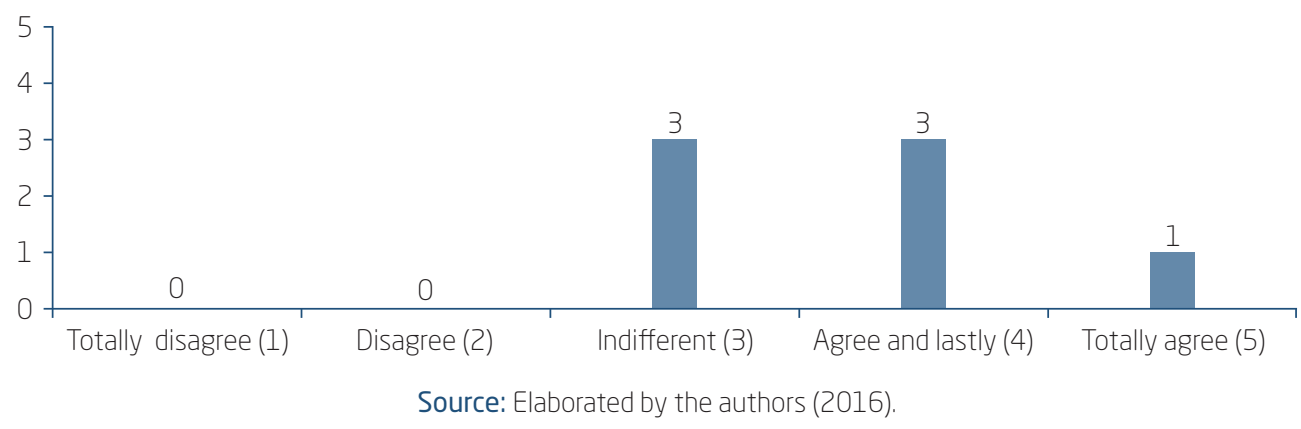

In question number one, it is evaluated how the collaborators qualify the tools that they use to be able to carry out their tasks according to the requirements of their activities, which can be as an article of stationery, time controls, among others. The results show that three of the seven collaborators surveyed agree with the question, three other people are indifferent to the tools they use for their work, and finally, only one collaborator totally agrees with the tools that he uses according to the content of the question. Only one person answered in fully agreeing on the tools provided by the micro business. Emphasis should be placed on the people who answered that they are indifferent, they may not have defined the use of the tools or do not know their potential.

\section{(Graph 2)}

HOW DO YOU FEEL ABOUT THE PHYSICAL CONDITIONS OF YOUR JOB?

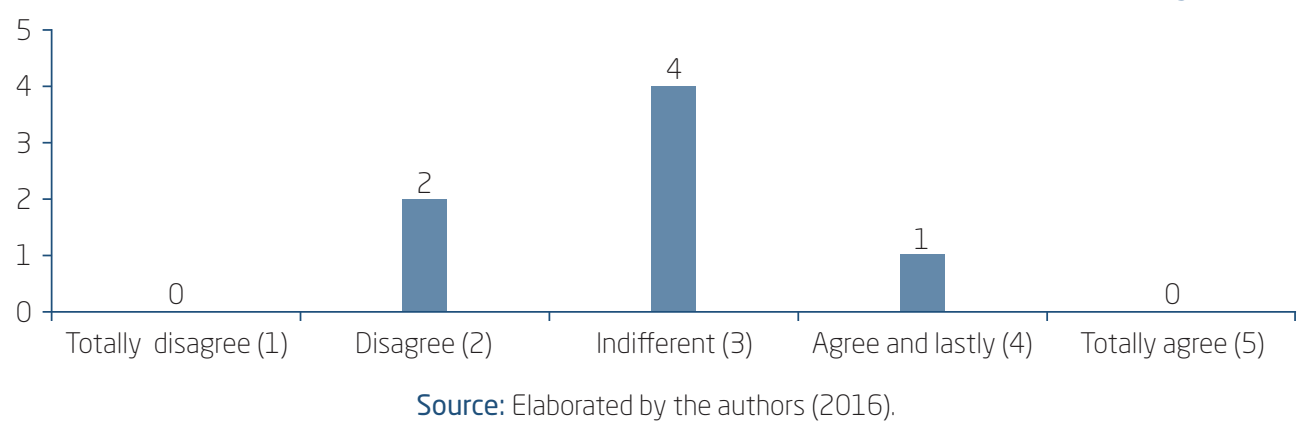

In Graph 2, the respondents are asked about the physical facilities, where the cybercafé is located. More than half of the collaborators seem indifferent 
to the facilities, that is to say, they are not influenced by the physical conditions of the establishment to perform their job. However, 2 people answered that they disagree with the characteristics of the place, in this point influenced by the furniture for use by the collaborators and the clients. That is, the opinion of the clients regarding the facilities intervenes in the opinion of the collaborators as well.

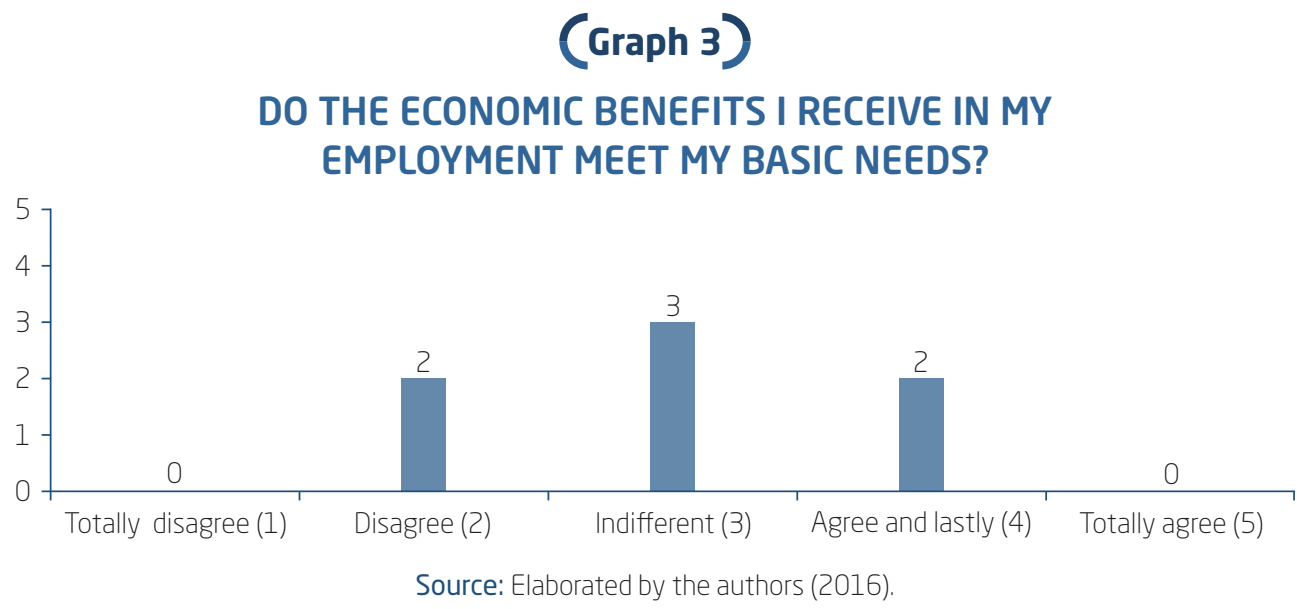

Graph 3 shows the importance of the monetary resource for the employees in relation to the motivation in this type of business. The part that had more coincidence is indifference with 3 people, who show their affinity to this answer, thus, it can be inferred that it is not clear what they can gain from what they know and the time that they dedicate to this activity. However, there are 2 people, who express their disagreement with the monetary perception received, this is because it is possible that these people have more seniority in the micro enterprise, and therefore, feel that the monetary resources they receive are insufficient.

For those who answered that they agree with their salary, it is probable that they administer the resources in a more structured way, or that the personal expenses are not completely inaccurate or are controllable. It can also be considered that there is an option of having extra tickets by other means and the resources obtained in the cybercafé do not cover their total expenses. In some cases, the salary is proportionally related to the skills and the knowledge, therefore, for those who chose to agree, the current perception is feasible. 


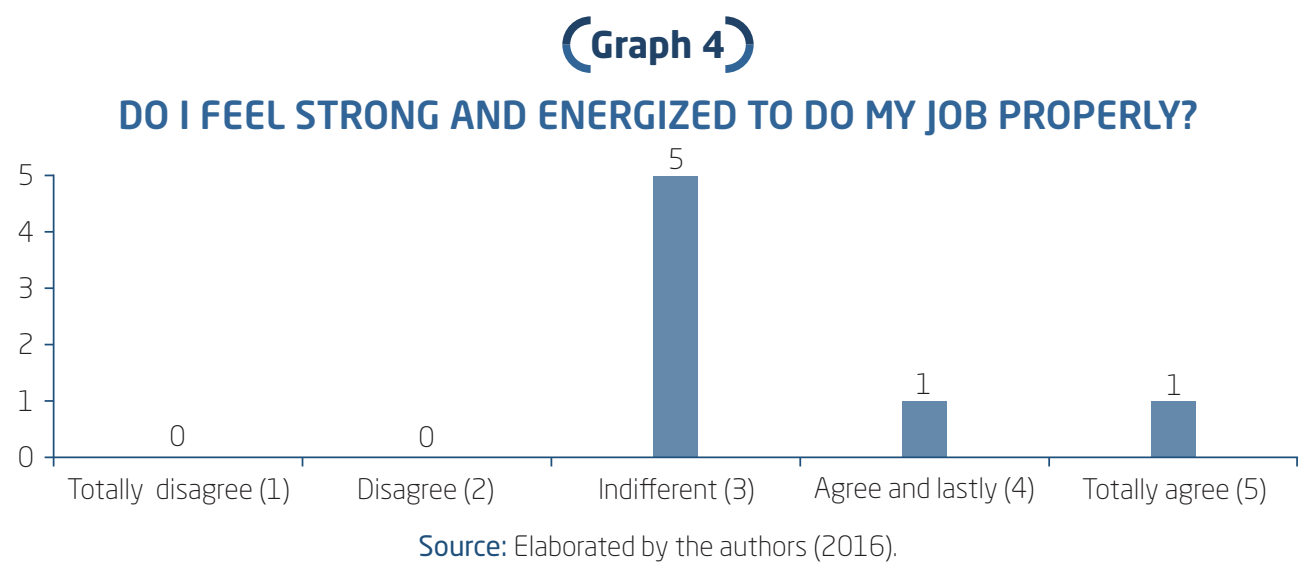

Chart number 6 addresses the more personal issue of the workers because it mentions part of the state of mind and energy to perform their tasks. From the total of 7 collaborators, 5 are indifferent about the relation of the mood and their activity, therefore, it can be inferred that their work can be monotonous and that it does not motivate them to improve their state of mind, that is to say, the greater part of the staff is unmotivated to do their job properly. On the other hand, only one person agrees to feel motivated and energetic in carrying out his work. Likewise, one person mentioned to being totally in agreement in feeling with the spirit and energy to carry out his works. In general, for the staff that works in this cybercafé, no factors are found to detonate the motivation for their work activity.

Needs of association or acceptance. In this section, three questions are focused on the part of the team work, and how the micro business creates conditions for the generation of synergy among the collaborators in order to foster fellowship and communication among members of the business.

\section{(Graph 5)}

DO YOU BELIEVE THAT THE COMPANY ENCOURAGES FELLOWSHIP AND UNION AMONG WORKERS?

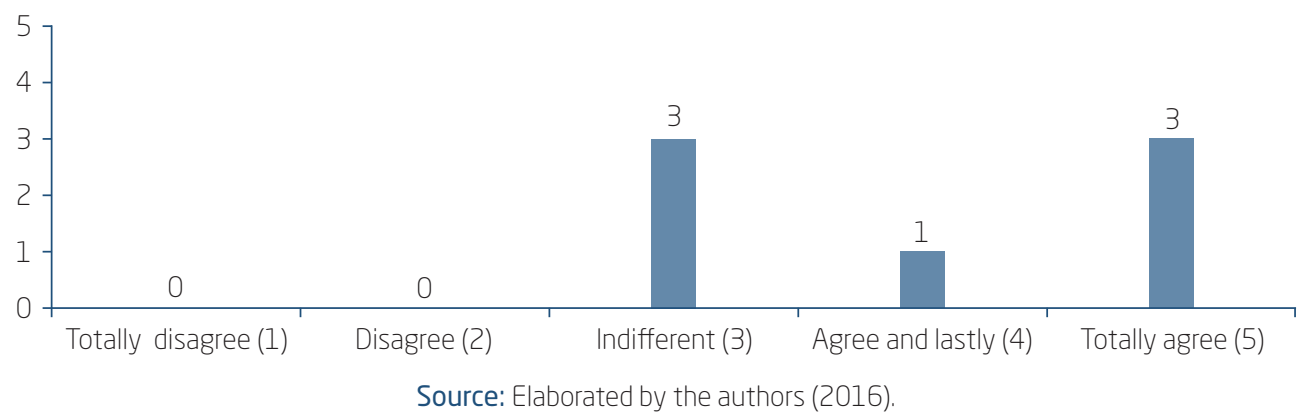


In Graph 5 it is observed that for 3 collaborators, it is indifferent whether the micro-enterprise fosters the companionship and the union between the collaborators, that is to say, they show no interest in working in a team. However, 3 other people fully agree with effective communication between collaborators and therefore, on working as a team. Only one person agrees with the above. This situation can be complicated, because there are 2 types of equipment in the organization, and one can contaminate the other and create a conflict over teamwork and communication. It is even likely that there will be more preference on the part of the administration with some people and this may create conflicts.

\section{(Graph 6)}

DO I THINK MY BOSS HAS GOOD WORK RELATIONSHIPS WITH ME?

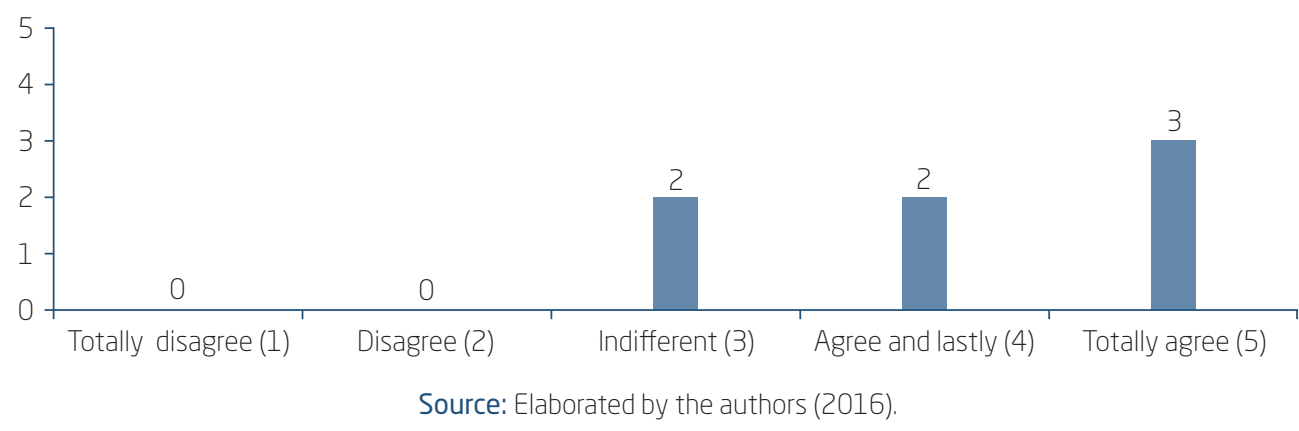

The working relationship between the boss and the collaborators of the cybercafé is shown in Graph 6 where two people express their indifference to the relationship they maintain with their boss, which can lead to a poor interpretation of the orders given from the boss to the subordinate. Only two people agree with the form of communication they maintain with their boss, and three people fully agree with how the communication between the subordinate and the boss develops.

When talking about an efficient work team, it is convenient to know the relationship between employees and how they feel interacting with each other. Therefore, Graph 7 refers to the integration among the same collaborators, where the overall results are not encouraging. Indifference is evident in three people, that is, not interested in how they feel about being a team member. Also, there is 1 person who disagrees with how he feels about the organization with regard to his co-workers; this can lead to severe conflicts between workers. 


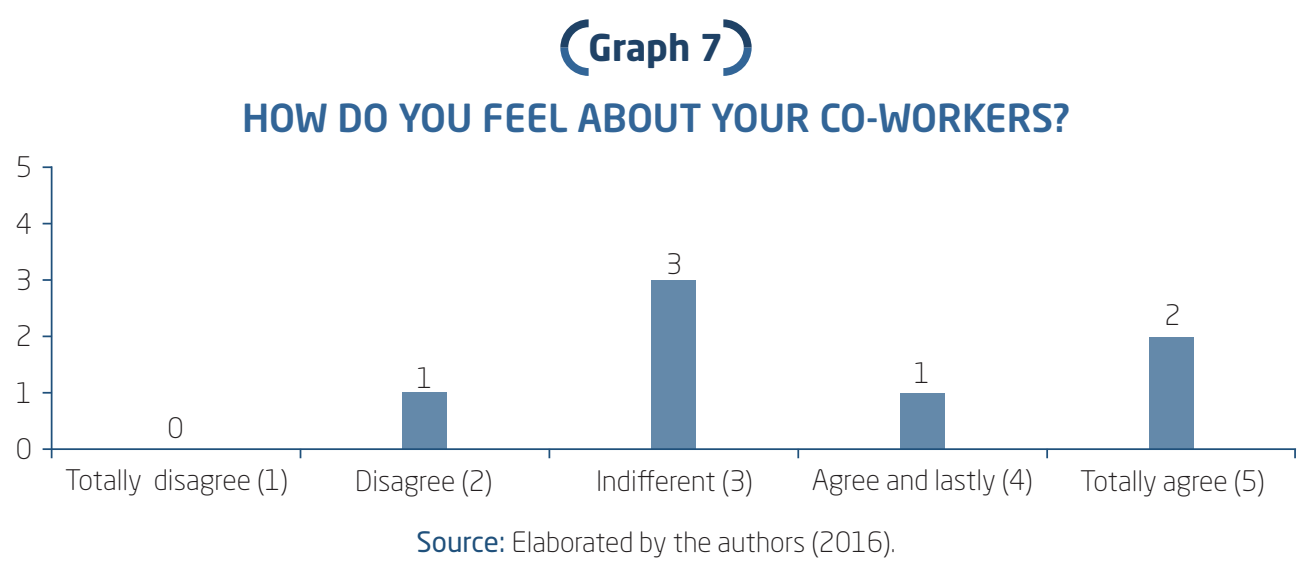

On the other hand, there are two people who totally agree with how they feel about their peers and only one agrees with the same concept. In the following segment of Graphs from 8 to 11, the focus is on the motivation to the area of estimation, where the employees reflect the status and the responsibility among others. Also, let the others recognize their activities and achievements within the company.

\section{(Graph 8)}

DO YOU CONSIDER THAT THE COMPANY TAKES YOUR OPINIONS

REGARDING THE TASKS YOU ARE CARRYING OUT INTO ACCOUNT?

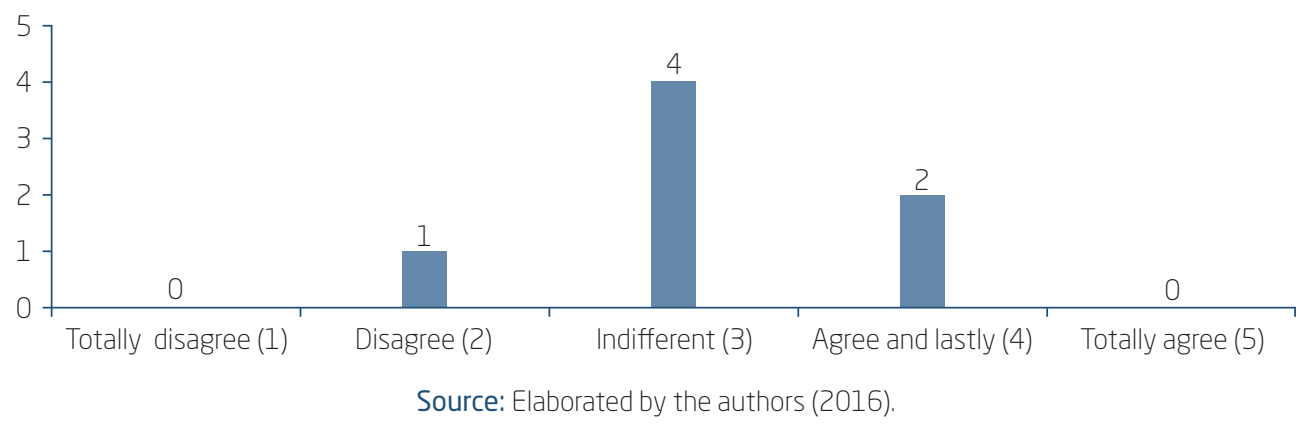

The human being needs recognition from others of the activities he performs; this may be an indicator to feel motivated. In Graph 8, the indifference of four members out of the seven in total is worrisome, that is to say, these four collaborators feel that their opinions, as far as they know by now, are not taken into account. One person thinks he disagrees that the organization does not take their opinions into account. However, there are two people who think that the company takes their contributions into 
account. In general, these results reduce motivation and it is possible that the collaborators focus on individualism.

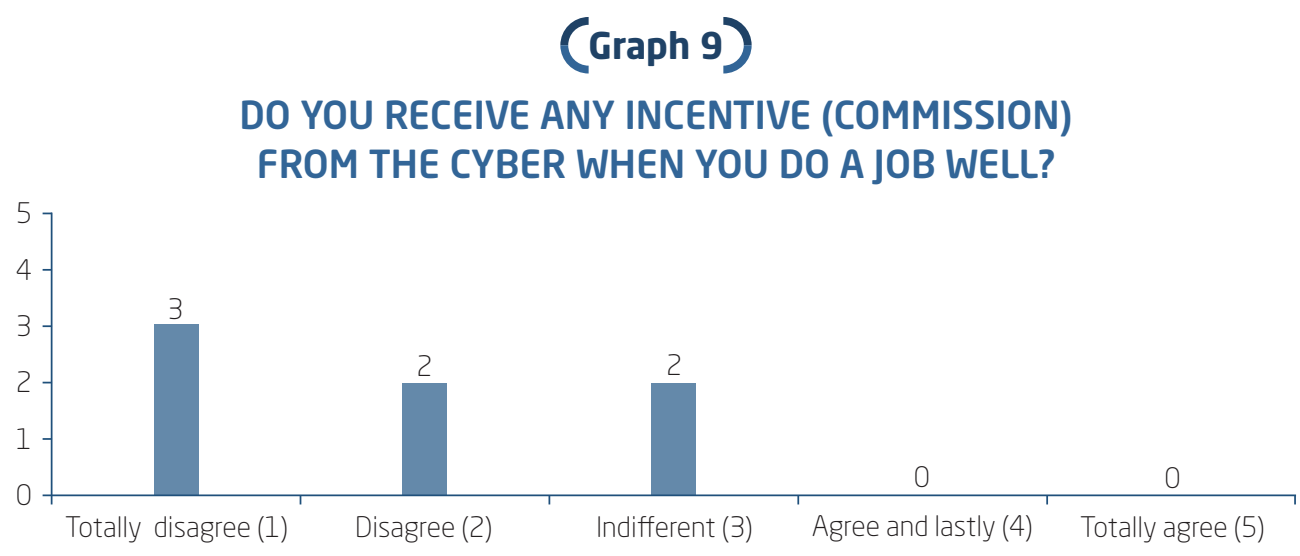

Source: Elaborated by the authors (2016).

Monetary incentives for employees are an important part of any forprofit organization. It is a motivating factor to continue working in the company, and it is clear that the human being needs money to survive and acquire basic products to survive. In this area, it is necessary to know under what economic conditions the company is in order to be able to encourage its employees. In Graph 9, one of the most striking results for the cybercafé is shown, that is to say, it is in the critical area of the graph, where the results are not encouraging to exercise motivation on the collaborators. Three of the seven people totally disagree with the monetary resources they perceive, two of the contributors disagree with this concept and only two disclose their indifference in this concept. In this organization, the economic compensation for performance is almost null; therefore, motivation based on incentives is negative.

Within the estimation needs, it is important that the organizations recognize the work and their collaborators and let them know by the appropriate means. In some cases, the non-economic recognition by the managers towards their collaborators becomes important. In Graph 10, the indifference becomes relevant in the concept of the recognition of the bosses towards the collaborators, where five people agree with the aforementioned results. That is, the collaborators do not care whether their work is recognized or not. It is possible that this organization will fall into monotony and lose the sense of recognition as a catalyst for motivation. Likewise, the two remaining people disagree and state that their work within the organization is not recognized. 


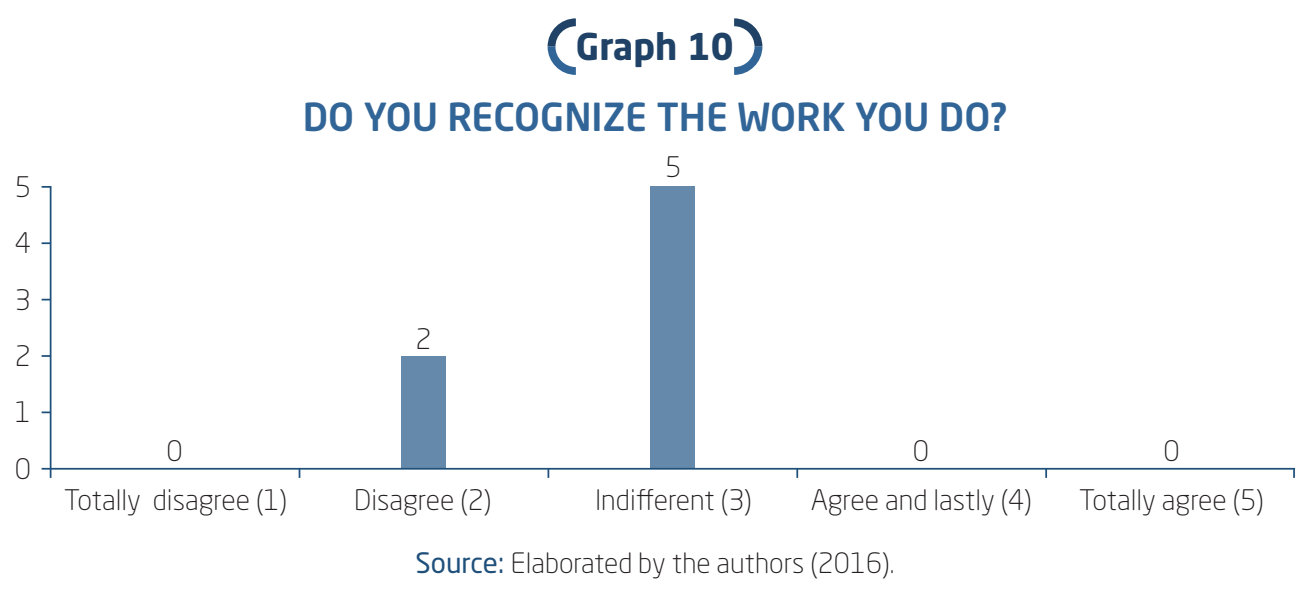

(Graph 11)

DOES THE RISK OF FAILURE IN THE TASK YOU ARE UNDERTAKING MAKE YOU WORK HARDER?

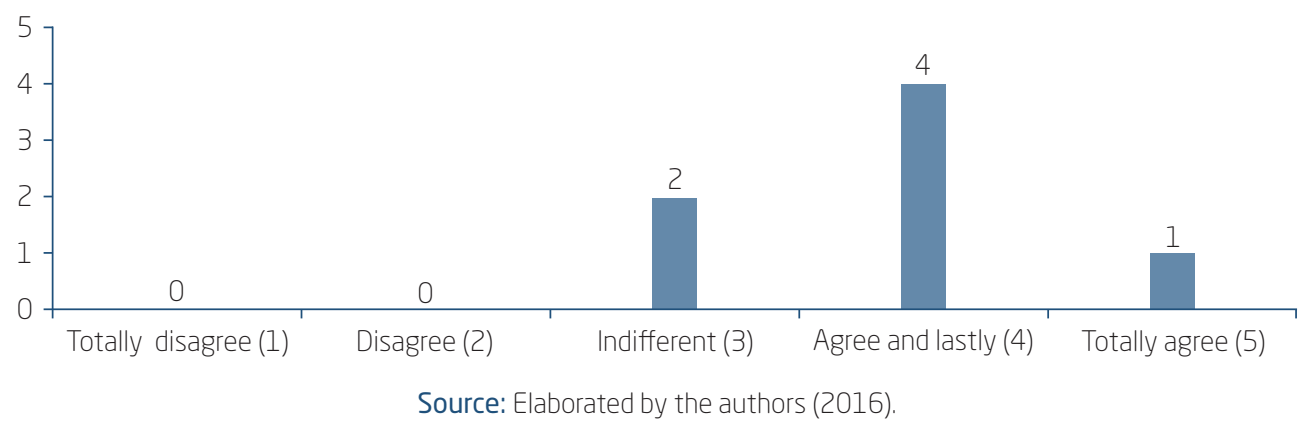

The risk is inherent in all activities to be performed, and it is common for people to relate risk to failure. In some cases, people feel at risk when they have to face it and strive to reduce it. Although these terms are more related to personal issues, they are reflected in the daily activities of the organizations, as the case in Graph 11, where four respondents agree that facing the risks in the work activities makes them strive. This leads them away from failure. In addition to the above, only one person fully agrees to assume the risk to carry out their activity. On the other hand, this concept seems indifferent to two employees, that is, to remain in a comfort zone. Specifically, a risk is part of the motivation.

The need for self-update is focused on personal issues predominantly. It is the culmination within the Maslow pyramid. In organizations, selfrealization needs influence, because if the individual is satisfied with 
himself, the activities that he develops in the organization are likely to be of high quality.

The activities carried out by the employees must be remunerated by the organizations. For this, the individuals must have a motivation that encourages them to perform some activity in exchange for remuneration they can into the acquisition of some goods or service that are important for them.

\section{(Graph 12)}

I'M GOING TO WORK BECAUSE I CHOSE TO DO IT TO GET WHAT I WANT

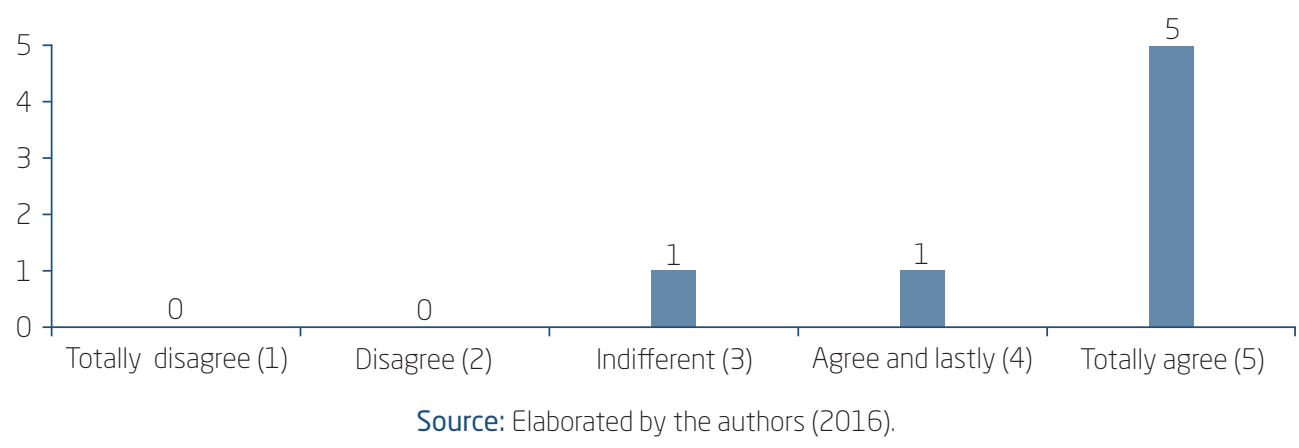

With reference to Graph 12, in the section of totally agreeing, 5 collaborators agreed that they will work because they decided, in order to get recourses to obtain what they need. Likewise, one single person agrees with this concept, and the remaining person was indifferent to this approach.

\section{(Graph 13)}

\section{AM SATISFIED BECAUSE I HAVE BEEN ABLE TO CONTRIBUTE TO THE PROCESS OF THE KIND OF WORK I HAVE DONE}

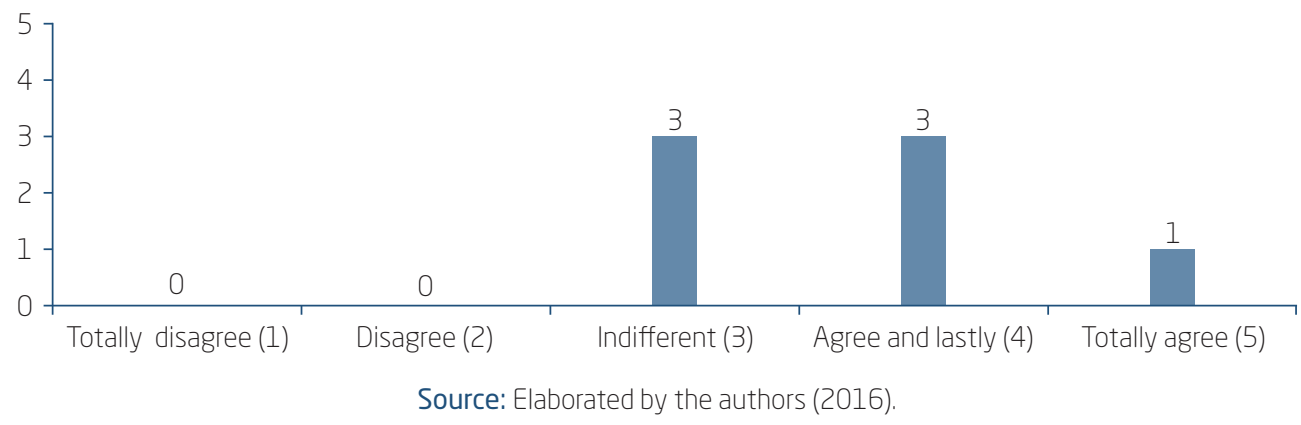

Satisfaction is an important part of the need for self-realization. It is an indicator for people who want to achieve a goal. Job satisfaction in some 
cases is manifested when the actions proposed by the collaborator are materialized within the organization, which is why it feeds motivation and urges us to continue to propose strategies that help the organization. In Graph 13, the collaborators express their opinions on this topic, where three of the collaborators remain indifferent to the contributions that they could make to the organization.

The same number of employees mentioned above agree with the contributions made to the organization and only one employee totally disagrees in this area. In some cases, the employee is motivated by the fact that his projects are carried out in the organization, without being affected if he receives the comments on the work done verbally or in writing, but this depends more on personal matters.

\section{(Graph 14) \\ I AM GOING TO WORK BECAUSE IT IS MEANT TO CARRY MY PROJECTS OUT}

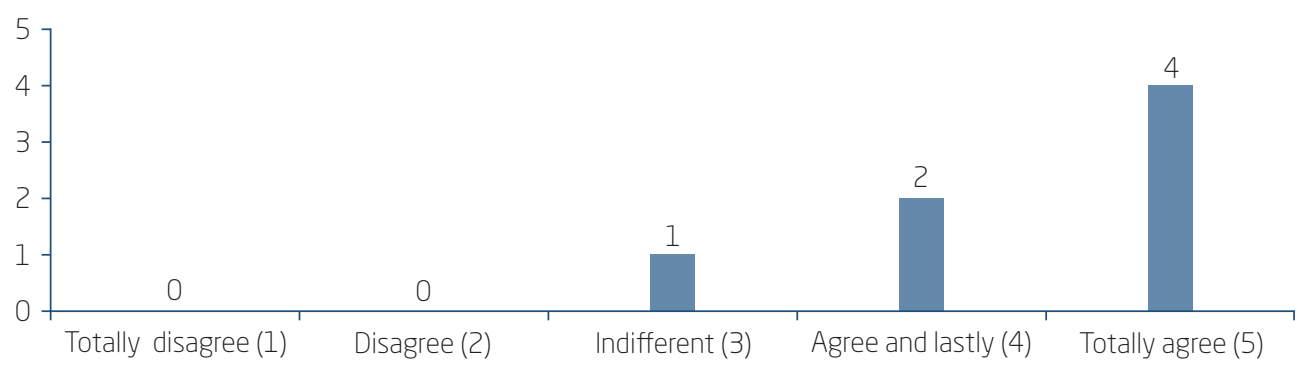

Source: Elaborated by the authors (2016)

In self-realization, it is advisable to have a clear recognition of intangibles and materials. The latter are in monetary matters, so when the collaborators determine a project to be carried out, they know in advance that resources are needed to develop it. This resource can be obtained through the exchange of goods and services; the employee delivers his knowledge, time and labor, in return for an economic reward from the company.

In the case of the cybercafé, most of the collaborators completely agree with the assertion that the work is meant to achieve their goals. Only 2 collaborators agree and only 1 seems indifferent to the approach of the survey. Therefore, when the situation of both the employee and the company is clear, it is very possible that they agree that the relationship between the two is the exchange of benefits for both according to their projects. 


\section{CONCLUSIONS}

Labor motivation in the family micro-business partners may be a little complex to address under the theories or models that have been developed, because of the environment in which these family companies are set up and operate. It is clear that for this type of organization, to develop a system of recruitment and training would be a problem for its implementation, evaluation, and monitoring, due to costs, time and mostly, because of the organizational culture.

Maslow's pyramids of needs are taken as a reference for the evaluation of labor motivation, supported by an instrument for the breakdown of the people's needs. It should be noted that other positions and theories of different authors have coincided in several elements of the motivation. It is also appropriate to specify that variations in the results have a margin of error, due to the collaborators' emotional situation and influence at the time the survey was answered.

The results presented by the study of job motivation in the cybercafé are not favorable to the company, due to the representativeness showed by the "indifferent" option chosen by the employees in the scenarios presented in the questionnaire. This can create uncertainty due to impartiality or to some extent insecurity of the employees when choosing the option "indifferent".

Part of a possible solution to this scenario on job motivation lies in the lack of communication and integration among employees, coupled with tools and facilities, either because they are deficient or because the staff is not trained to use them. However, the most complicated problem is in the monetary compensations, since the results were deficient for this item. In this case, it is important to evaluate the financial capacity of the company to establish a plan of economic incentives and to increase the motivation among employees and thus seek to increase productivity and profitability of the company.

\section{$\int$ REFERENCES}

Ackoff, R. L. (1997). Planificación de la empresa del futuro. México: Limusa. Becerra Sánchez, G. M. (2011). Los cibercafés de Guadalajara. Guadalajara, México. Universidad de Guadalajara, Sistema de Universidad Virtual.

Bourne, L. (1976) Psychology: its principles and meaning. New York: Hol, Rinchart and Winston. 
Carrillo, M., Padilla, J., Rosero, T. \& Villagómez, M. (2009). ALTERIDAD: Revista de educación, 4(7), 20-32.

Castells, M. (2002). La era de la información, economía, sociedad y cultura (La sociedad red: Vol. 1). México: Siglo XXI.

Chiavenato, I. (2002). Gestión del talento humano. Bogotá, D.C. Colombia: McGraw Hill Interamericana.

Donnelley, R. G. (1964). The family business. Harvard Business Review, 45, 93-105.

Edvinsson, L., \& Mallone, M. (1999). El capital intelectual: cómo identificar y calcular el valor de los recursos intangibles de su empresa. Barcelona: Gestión 2000.

Finquelievich, S. (2002, february). Acciones globales para la inclusión social en la sociedad de la información: de consumidores a ciudadanos. Simposio Latinoamericano y del Caribe "La educación, la ciencia y la cultura en la sociedad de la información".

Fisher, H. (1984). ¿La calle a dónde llega? México: Arte y Ediciones.

García, A. E. (2008). Motivación individual. Retrieved from http://grupos. emagister.com/documento/administracion_motivación_y_organizacion_/ 1048-38669

García, N. C. (2008). La globalización imaginada (Estado y Sociedade: Vol. 76). Buenos Aires: Paidós.

García, J. F. I., \& Dávila, S. O. (2012). Modelo probabilístico de quiebra de la pequeña y mediana empresa española. Evidencia empírica. Un modelo econométrico. Contribuciones a la Economía. Vol. 67.

Gersick, K. E., Davis, J. A., Hampton, M. M., \& Lansberg, I. (1997). Empresas familiares: generación a generación. El modelo de los tres círculos. México: McGraw-Hill.

Giddens, A. (1994). Consecuencias de la modernidad. Madrid: Alianza Universidad.

Giddens, A. (2007). Un mundo desbocado: Los efectos de la globalización en nuestras vidas. Madrid: Taurus.

González V. (1822) Diccionario de la Real Academia Española. Madrid: Nepotismo (Ed. Abreviada).

Ibáñez (1998). Nuevos avances en la investigación social. Barcelona: Proyecto A Ediciones.

Koontz, H. \& Weihrich, H. (2007). Administración: una perspectiva global. Cd. del México: McGraw-Hill. 
López, A., Contreras R., \& Molina R. (2013) La empresa familiar como objeto de estudio. La toma de decisiones en la empresa familiar. México: Pearson Educación.

López-Cozar, C. N., \& Priede, T. B. (2009). Empresa familiar: claves para la supervivencia en un mundo cambiante. El triángulo de la empresa familiar. España: Gesbiblo. España. pp. 60-69.

Malgioglio, J. M., et al. (2001). Capital intelectual: El intangible generador de valor en las empresas del tercer milenio. Trabajo presentado en las Sextas Jornadas "Investigaciones en la Facultad" de Ciencias Económicas y Estadística. Rosario, Buenos Aires: Universidad Nacional de Rosario e Instituto de Investigaciones Teóricas y Aplicadas, Escuela de Contabilidad, pp. 350-370. Disponible en: www.fcecom. unr.edu.ar/investigacion/ jornadas/archivos/malgiogliocapital01.pdf. [Consultado en agosto de 2010].

Maslow, A. (1943) A theory of human motivation, Psycheiogicaí Review, 50 (4), 370-396.

McClelland, D., \& Burnham, D. (1976). Power is the great motivator, Harvard Business Review, 54(2), 100-110.

Moscovici, S., \& Hewstone, M. (1984). De la ciencia al sentido común, en Serge Moscovici, Psicología Social II, Barcelona: Paidós Paré.

Munch, L. G. (2005). Administración de capital humano. La gestión del activo más valioso de la organización. México: Trillas.

Naranjo, M. (2009). Motivación: perspectivas teóricas y algunas consideraciones de su importancia en el ámbito educativo, Revista Educativa, 33(2), 153-169.

Nelson, R. (2014). La familia, una empresa hoy, mañana; gestión, transición y sucesión. Editorial Brujas.

Nelson, R. R., \& Winter, S. G. (2002). Evolutionary theorizing in economics. The journal of economic perspectives, 16(2), 23-46.

Quintero, J. (2011). Teoría de las necesidades de Maslow. México. Retrieved from www.doctorado.josequintero.net

Robbins, S. (1998). Comportamiento organizacional. Cd. del México: Prentice Hall.

Santrock, J. (2002). Psicología de la educación. Cd. del México: Mc Graw-Hill.

Toudert, D., \& Buzai, G. (2004). Cibergeografía: tecnologías de la información y las comunicaciones (TIC) en las nuevas visiones espaciales. México: Universidad Autónoma de Baja California. 
Urzúa, J. J. (2012). Empresas familiares: lo primero es el negocio. Retos de la empresa familiar en un mundo globalizado. Retrieved from http://www.conpapa. $\operatorname{orgmx} /$ files/congress/2012/conferences/empresas_familiares_primero_ negocio.pdf

Wayne M. R., Noe, R. M., \& Premeaux, S. R. (1997). Administración de Recursos Humanos. (6. ed.), México: Prentice Hall.

\section{ABOUT THE AUTHORS}

\section{JOSÉ G. VARGAS-HERNÁNDEZ}

Research Professor from the Center for Economic and Managerial Sciences, University of Guadalajara (UdeG).

Periférico Norte 799 Edif. G201-7, Los Belenes Zapopan, Jalisco - México - CEP 45100

E-mail: josevargas@cucea.udg.mx

\section{JOSÉ ANGEL ARREOLA ENRÍQUEZ}

$\mathrm{PhD}$ in Business,

Research Professor from the Center for Economic and Managerial Sciences, Universidad de Guadalajara (UdeG).

Periférico Norte 799 Edif. L308, Los Belenes Zapopan, Jalisco - México - CEP 45100

Email: angel.arreola@academicos.udg.mx 